\title{
A Comparison of the Stem Anatomy of the Cohort Umbelliflorae.
}

\author{
BY
}

\author{
CARL S. HOAR. \\ With Plates IV and V.
}

A $\mathrm{S}$ classified at present, the families Cornaceae, Araliaceae, and Umbelliferae are placed together under the cohort Umbelliflorae. This cohort is in turn placed at the top of the sub-class Archichlamydeae, next to the sub-class Metachlamydeae. Such is the classification given by Engler and Prantl and followed by Engler and Gilg (1).

The closeness of relationship between the families of this cohort has always been more or less in doubt. Because of this doubt I have made, during the last year, a special study of the stem and root anatomy of the three families. My purpose in so doing has been to learn what additional evidence I might obtain as to their true relationships. In pursuing this study I have concerned myself especially with the Cornaceae, having been able to obtain all of the genera and many of the species native to this region, together with several which are of exotic origin. With the other two families I have had a smaller number of examples, but their constancy of common characteristics seems to confirm my conclusions.

Of the three families, the Cornaceae are generally considered to be the lowest, while the Araliaceae are placed between the former and the Umbelliferae. Such a view might easily be drawn from external characters alone. The Cornaceae are, with one or two exceptions (Cormus canadensis), shrubs, which sometimes, as in the case of Nyssa sylvatica, become tree-like in appearance. The Araliaceae would seem to stand in an intermediate position, since, although they are often shrubby and even tree-like, yet the wood is seldom as well developed, and many of its members are herbaceous. Finally, the Umbelliferae would seem to be the highest since its members are always herbaceous, with very little wood. It has been conclusively shown that herbaceous plants are derived from the woody plants, frequently by the formation of large rays and the decrease of the amount of woody elements $(2,2 a)$. For this reason the external appearance of the three families gives the basis for the conclusions which are shown to be true when the flower and stem anatomy are taken into account.

[Annals of Botany, Vol. XXIX. No. CXIII. January, 19I5.] 
The family Cornaceae is composed, according to Engler and Gilg's classification, of three sub-families, namely, the Mastixioideae, the Curtisioideae, and the Cornoideae. From this family they separate the sub-families Nyssoideae, Davidioideae, and Alangioideae, placing them under the order Myrtiflorae. As I shall attempt to show later, the evidence for such a separation is lacking when the anatomy is taken as the criterion.

Of the various genera of the above sub-families, I have been able to secure examples of Cornus, Nyssa, Davidia, Griselinia, Aucuba, Corokia, Mastixia, and Helwingia. In the case of Cormus, Nyssa, Griselinia, and Aucuba, I have had specimens of the roots as well as of the stems.

Regarding the general anatomical characteristics of the Cornaceae we are indebted chiefly to the work of Sertorius (3). It would seem best, perhaps, to insert here some of the more important anatomical characters which he found in his study of the stem axis. The cork arises usually sub-epidermally, though Moller and Weiss state that the phellogen in Aucuba and in some species of Mastixia arises from the epidermis. Collenchyma appears in the cortex in nearly all cases, though none has been reported for Mastixia. Cortical bundles appear only in the case of Mastixia, and are due there to the leaf-trace which passes down in the cortex for a short distance before entering the wood. The hard bast, as de Bary (4) has noticed in Cormus, is found only in the primary wood, except in Mastixia, where it is formed secondarily and stretches irregularly throughout the soft bast, with no definite arrangement. In Marlea begoniaefolia, Helwingia, and Aucuba japonica no hard bast appears at all. Stone cells are quite common throughout the family.

In regard to the woody axis proper, I will speak first of the vessels. According to Sertorius these are nearly always scalariform. In the genera Alangium, Torricellia, and Marlea, however, there is a single pore in the secondary wood. However, the pore is often drawn out, and in the primary wood bars are found. In some of the above instances one or two bars have been found appearing even in the secondary wood. The vessels themselves are usually small and isolated, with a four-sided appearance from a transverse view. The walls, according to Sertorius, have always bordered pits where the vessels come in contact with the parenchyma of the rays, though Solereder (5) finds simple pits where Griselinia is in question. The wood parenchyma has only bordered pits in some cases, while in others it may have both kinds or only the simple pits. Septation of tracheides is not a common feature, though Solereder reports it for Marlea, and I have also noticed it in Aucuba japonica and Griselinia lucida root. The rays are in general small, being from one to five cells in width. In our native species they are not very abundant, but in some of the exotic genera, such as Griselinia, Corokia, \&c., the rays are very numerous, and the individual cells are often quite large. 
Among the members of the Cornaceae, Mastixia stands out as peculiar. I have already mentioned the peculiarity in regard to the secondary hard bast, and in regard also to the presence of cortical bundles. There is yet another peculiarity which is found in no other place in this family, but which is characteristic of the two higher families. This is the presence of secretory canals in the cortex and in the pith. The presence of these canals has caused much discussion concerning the true relationship of this genus. Baillon (6) placed it with the Araliaceae next in kin to the genus Anthrophyllum. Later, he reconsidered and changed his opinion. Van Tieghem (8) came, through his work, to the view that it belonged neither to the Cornaceae nor to the Araliaceae, but rather to the Dipterocarpeae. Later, he also changed his opinion. Burck (9) also came to the view that it stands very near to the Dipterocarpeae, though the Simarubeae and the Liquidambeae must also be taken into the reckoning.

Though the above opinions show that Mastixia is a much-discussed genus, and that its position is rather unsettled, yet the other characteristics would seem to indicate that it belongs to the Cornaceae, and here it is generally placed. Granting that Mastixia is one of the Cornaceae, it is argued that it must serve as a connecting link between that family and the Araliaceae. The basis for this argument is chiefly the presence of secretory canals in pith and in cortex. Such canals are a constant feature in the Araliaceae and in the Umbelliferae. In answer to the above argument it can simply be said that the presence here of secretory canals does not seem to be conclusive evidence, in this case, of a close relationship. We find in the family Hamamelideae that only the Altingeae, with Liquidambar as our common example, are characterized by internal secretory canals. Secretory canals also occur in some members of other families, while they are lacking in other members of the same family. Here, evidently, their presence or absence does not change their relationship. Only in such families as the Araliaceae and the Umbelliferae, where they are present in every member, are they evidence of close relationship. In the Cornaceae, they are found only in Mastixia. Hence they are not characteristic of the family, and would not seem to me to be of great value in showing relationship where that family is concerned.

Having now spoken of the more important and noticeable anatomical features of the Cornaceae, let us turn briefly to the like features in the Araliaceae and in the Umbelliferae.

In the Araliaceae secretory canals are present throughout the entire family, being present in all parts of the cortex and often also in the pith. Another peculiarity found nowhere among the Cornaceae is the presence of medullary bundles. These are formed in a ring, having collateral structure, and being inversely orientated so that the xylem is towards the outside. I have noticed these in the petiole of Aralia chinensis var. manchuria, 
though they occur nowhere in the main stem. It is generally conceded that the leaf is more conservative than the stem, and hence we might expect that medullary bundles are an ancient character of the Araliaceae. However, they are not found in the Cornaceae, which are considered to be lower in the evolutionary scale.

In regard to the wood of the Araliaceae, we find often very broad rays which, in the herbaceous species, entirely separate the bundles. The vessels have generally simple, elliptical perforations. In two instances (Gilbertia and Fatsia) a few bars occur showing an indication of a transition to the scalariform type. The end walls of the vessels are more or less inclined to the lateral walls. Their lateral walls when in connexion with parenchyma of the rays commonly have simple pits. As regards the wood prosenchyma, the pits are always simple and we find delicate septations. Such cells often contain starch, and are called 'septate tracheides'.

Finally, in the stem of the Umbelliferae the cortex often contains strands of collenchyma which lie directly under the ribs appearing upon the outside. Sometimes these are lacking or are replaced by a ring of sclerenchyma. The fibro-vascular system is normally in the shape of a ring of bundles, with often medullary bundles in addition. The bundles are usually isolated, though sometimes they are fused together and are continuous. Their rays are usually either uni- or biseriate. The vessels have usually simple perforations, though sometimes the scalariform type is found accompanying them. The pitting, where the vessels are in contact with the parenchyma of the rays, may be simple or bordered. The wood prosenchyma shows both simple and bordered pits. Anomalous structures sometimes occur, such as cortical bundles and an extra-fascicular vascular ring. The pith is usually lost in the internodes, thus leaving the stem hollow.

Having briefly summed up the situation, and having stated the general anatomical characters of the order, I will now describe in some detail the results of my investigation. Past evidence from material worked over in this laboratory seems to indicate that the distribution of parenchyma is one of the most important and reliable anatomical characters found in plant anatomy. In the Gymnosperms we find it either at the end of the year's growth (terminal) or scattered throughout the annual ring (diffuse). In general, among the Dicotyledons the lower families have their parenchyma scattered throughout the annual ring (diffuse), while higher families have it clustered about the vessels (vasicentric). This character has been found to be so constant and of so great value that it has aided much in determining the relationships between families. Thus the Rosaceae, which from a systematic standpoint seem to be close to the Leguminoseae, show a different type of parenchyma distribution and hence, apparently, a much more remote relationship than is ordinarily assigned to them.

Thus far in the anatomical study of the Umbelliferae the value of the 
distribution of parenchyma in determining relationships seems not to have been realized. Because of this I have paid especial attention to the subject in my investigation.

As stated above, the terminal connexions of the vessels of the Cornaceae are generally scalariform, while those of the Araliaceae and of the Umbelliferae are characteristically simple elliptical or round pores. I have noted the condition of the terminal openings in my study, and have found results which corroborate the above statements. The condition of the terminal connexions between vessels is not as constant as is the distribution of parenchyma, but it may be mentioned here as worthy of notice.

In recording my results I will first speak of the Cornaceae, it being usually considered to be the lowest family of the three. Among the genera of this family the commonest native genus is Cormus. Pl. IV, Fig. I shows the type as illustrated in a transverse view of the species Cormus sanguinea. Here may be plainly seen the heavy-walled tracheides, the few small rays, and the numerous diffuse parenchyma cells. In Pl. IV, Fig. 2 one may see a radial view of the same species, and the same features may be noted. The genus does not always show such heavy walls, nor is the parenchyma always as abundant. However, the relationship as regards the distribution of parenchyma and the character of the end walls of the vessels persists.

In Pl. IV, Fig. 3 we see a transverse view of the stem of Nyssa sylvatica. Here the parenchyma is plainly diffuse, and in other ways the wood closely resembles that of Cormus. Fig. 4 is a higher power of the same view as that shown by Fig. 3. Fig. 5 is a radial view of the same, and here we can see the even closer resemblance to Cornus, the parenchyma being more strikingly diffuse than in the transverse view.

Here I would call attention to the fact that, under Engler and Gilg's classification, Nyssa is placed outside the Cornaceae. Certainly the anatomical structure would not appear to warrant this.

Turning from our native forms to those exotic to this region, we find the parenchyma much less abundant. However, in Davidia involucrata (Fig. 6) one can plainly see the diffuse parenchyma and the scalariform vessels from the radial view. The number of bars in the vessel seems to be much more numerous than the number in the case of Cormus, but even among members of the same genus we find much deviation from the small number. Davidia is another genus placed by Engler and Gilg outside the Cornaceae. Clearly this would not seem possible when the internal anatomy is considered.

In some exotic species the parenchyma appears to be entirely lacking. Its absence, however, is a common characteristic in plants living in a climate where the storage of food is not necessary. In most instances I was able to find remains of parenchyma cells, showing their persistent character.

Fig. 7 is that of a radial section of the stem of Griselinia lucida. 
This has in most instances the parenchyma transformed into substitute fibres. However, the above figure, which is one of several examples, shows clearly the parenchyma as being diffuse. In cases where the root of the same species was in question, a much greater quantity of diffuse parenchyma appeared. Pl. IV, Fig. 8, a transverse section of the root, and Fig. 9, a radial section of the same, show that that root was dead, and though the cause may have been natural or through wounding, in either case we have the parenchyma appearing according to the laws of reversion or retention.

In Griselinia littoralis no well-formed parenchyma appeared. However, there are a large number of cells filled with starch which were clearly substitute fibres. These are in a diffuse condition and clearly show that the plant at one time had diffuse parenchyma.

I have shown no other figures of members of the Cornaceae since it is impossible to represent their condition well by a photograph. My specimens of Mastixia and of Helwingia unfortunately are very small and will not allow any far-reaching conclusions. However, in both instances diffuse parenchyma was found. I hope some time to be able to secure larger specimens, in order to study more thoroughly their structure.

In the stem of Corokia, though it shows no well-formed parenchyma, yet the wood cells in certain regions show distinctly the clustered simple pitting so characteristic of the wood parenchyma cells. Often starch also shows in these. They are clearly substitute fibres showing the persistence of the parenchymatous characteristics.

My material of Aucuba japonica unfortunately shows no case of wood parenchyma, whether or not it is because the stem and roots were small I cannot be sure. However, the rays are so abundant and so close together that there is scarcely room for, and no use for, parenchyma. Septate tracheides seem to be present to some extent, and many wood cells show nuclei. Here, also, spiral thickenings often appear upon the walls of the tracheides, a condition not at all common to the other members of the family.

Turning now to the Araliaceae, I have been able to study genera including Aralia, Acanthopanax, Scheffera, Panax, and Hedera. In all cases where parenchyma appears it is clearly vasicentric. Pl. IV, Fig. Io shows a transverse view of a species of Schefflera. It is hard to demonstrate parenchyma from this view. Yet if one looks in the vicinity of the vessels it will be seen that the cells here have thinner and darker walls than those of the general tracheary tissue. The two large vessels just below the centre of the figure show themselves to be nearly enclosed by small cells. Fig. I I shows a radial section of the same species. Here at each edge a vessel may be seen, and clustered over and about it are rows of parenchyma cells. In Fig. I2, which is also a view of the same species, but is tangential instead of radial, the parenchyma may be seen round the vessels. Here in the centre may be seen a number of septate tracheides. These may be easily told 
from the wood parenchyma, since they have very thin cross partitions which lack the middle lamella. In Pl. V, Fig. I 3 one may see the radial view of Acanthopanax senticosus. Upon the right appears a single row of parenchyma cells adjacent to a vessel. It may be seen that the end wall of the vessel is pierced by a simple elliptical pore. The above characteristics show throughout the genera studied, though in many cases the presence of septate tracheides serves partially to obscure them.

In the last family, the Umbelliferae, I found the same conditions of parenchyma as that characteristic of the Araliaceae. In Pl. V, Fig. I4 we have a transverse view of Cicuta bulbifera. At first glance no parenchyma is seen, but upon further study the end walls of the parenchyma cells with their simple pitting may clearly be observed. These cells, it will be noticed, lie adjacent to the vessels. Fig. I5 is that of a tangential view of the same species. Here also the parenchyma shows itself to be only adjacent to the vessels. In Fig. 16 , which is a radial view of Cicuta bulbifera, we see an example of the vasicentric parenchyma characteristic of the family. It also shows the end pore of the vessel. Here it will be noticed that the pore is rounder, and that the end wall is more at right angles to the lateral walls than was the case with the Araliaceae as shown by Acanthopanax senticosus.

In Fig. I 7 and in Fig. I 8 are seen good examples of diffuse and of vasicentric parenchyma, in cases where such a condition has been recognized. Fig. I 7 is that of a transverse view of Fuglans nigra, and shows the diffuse type, while the vasicentric type is illustrated by the transverse view of Fraximus americana as shown in Fig. I8.

To sum up the results of my study, I find that in Cornaceae the parenchyma, where clearly present in specimens studied, constantly shows a diffuse distribution, and the vessels possess the scalariform type of perforation in their end walls. Native species show parenchyma of varying abundance, but nevertheless quite evident, and the rays small. In exotic genera, on the other hand, the parenchyma, where present, is scarce, and the rays are larger and much more abundant. The wood in the latter case sometimes shows septate tracheides, though they are not at all characteristic of the family. In Aucuba japonica spiral thickenings often occur upon the tracheide walls.

In the Araliaceae the parenchyma is always vasicentric. The vessels, moreover, show usually simple elliptical pores in their end walls. These pores are usually at a strongly oblique angle to the lateral walls. Septate tracheides are a common character of the family.

The Umbelliferae show the parenchyma vasicentric as in the case of the Araliaceae. The end wall of the vessels, also, usually show simple pores. Here, however, these are nearly round in circumference, and are nearer at right angles to the lateral walls. 
As to the constancy of the scalariform perforations of the vessels in the Cornaceae, I have already noted that simple perforations do occur in a few cases mixed with the scalariform type. In the Araliaceae the vessels have nearly always simple end perforations, though some species also show a few bars. The angle of the perforation is usually quite oblique to the lateral walls, and its circumference is usually elliptical. The Umbelliferae have simple perforations at the ends of the vessels, and these are often round and more at right angles to the lateral walls than in the case of the Araliaceae.

It has already been pointed out that in the sieve-plates of the sievetubes, the higher Angiosperms tend to lose their lateral plates, and the end plates come to take up a position more at right angles to the lateral walls (10). This seems to hold true for the perforations of the end walls of the vessels of the higher Angiosperms. I can make no definite statement here without a broader study of the subject, but merely offer this as a suggestion.

\section{ConClusions.}

I. That throughout the Cornaceae the parenchyma, where it occurs, is scattered throughout the whole annual ring (diffuse), while throughout the Araliaceae and Umbelliferae it is grouped about the vessels (vasicentric).

2. That the vessels of the Cornaceae show in every species examined, at least in part, scalariform perforations, while all species of the Araliaceae and the Umbelliferae show in part the simple pored condition. Also, that the simple pores of the Araliaceae are more elliptical and more oblique than in the case of the Umbelliferae.

3. That the general anatomical features of the Nyssoideae and Davidioideae do not seem to warrant their being separated from the Cornaceae and their being placed with the Myrtiflorae.

4. That the presence of secretory canals in Mastixia is not necessarily of importance in determining the relationship of the genus.

5. Finally that, using the anatomy as a criterion, the Cornaceae should not be placed in the same cohort with the Araliaceae and with the Umbelliferae.

The writer wishes, in closing, to express his gratitude to Professor Fernald, to the Director of the Harvard Botanical Garden, and to the Director of the Arnold Arboretum of Harvard University for specimens. Many of the species studied were secured by Drs. Eames and Sinnott in New Zealand by means of a gift of Mr. J. S. Ames, This investigation has been carried on in the Phanerogamic Laboratories of Harvard University under the direction of Professor Jeffrey, and to him I am greatly indebted for advice and for the photomicrographs accompanying this article. 


\section{LITERATURE CITED.}

1. Engler and Gilg: Syllabus der Pflanzenfamilien. Siebente Auflage, Berlin, Verlag von Gebrïder Borntraeger. I9I2.

2. Bailey, I. W.: The Relation of the Leaf-trace to the Formation of Compound Rays in the Lower Dicotyledons. Ann. Bot., vol. xxv, No. cvii, Jan. I9I I.

$2 a$. Eames, A. J. : On the Origin of Herbaceous Type in the Angiosperms. Ann. Bot., vol. xxv, No. cvii, Jan. I9II.

3. Sertorius: Beiträge zur Kenntnis der Anatomie der Cornaceae. Bull. de l'Herbier Boissier, vol. i.

4. DE BARY : Vergleichende Anatomie der Vegetationsorgane, p. $54^{2}$.

5. Solereder : Systematic Anatomy of the Dicotyledons, vol. i, I908, p. $43^{2}$.

6. BAILLON : Adansonia, vol. iii, I863, p. 83.

7. - Histoire des plantes, vol. vii, I880, p. I68.

8. Van Tieghem : Annales des Sciences Naturelles, Bot., vol. vii, ser. I, i 885, p. 27.

9. BURCK : Annales du Jardin botanique de Buitenzorg, vol, vi, p. I54.

10. Hemenway, Ansel F. : Studies of the Phloem of the Juglandaceae. Bot. Gaz., vol. li, No. 2, I9I 2.

\section{DESCRIPTION OF FIGURES IN PLATES IV AND V.}

Illustrating Mr. Hoar's paper on Stem Anatomy of the Cohort Umbelliflorae.

\section{PLATE IV.}

Fig. I. Cornus sanguinea. Transverse section of stem, showing diffuse parenchyma. $\quad \times 100$.

Fig. 2. Cornus sanguinea. Radial section of stem, showing diffuse parenchyma and scalariform vessel. $\times 250$.

Fig. 3. Nyssa sylvatica. Transverse section of stem, showing diffuse parenchyma. $\quad \times 250$.

Fig. 4. Nyssa sylvatica. Transverse section of stem, showing diffuse parenchyma. $\times 400$.

Fig. 5. Nyssa sylvatica. Radial section of stem, showing diffuse parenchyma and scalariform vessels. $\times 250$.

Fig. 6. Davidia involucrata. Radial section of stem, showing diffuse parenchyma and scalariform vessels. $\times 250$.

Fig. 7. Griselinia lucida. Radial section of stem, showing diffuse parenchyma. $\times 250$.

Fig. 8. Griselinia lucida. Transverse section of root, showing tylosis of vessels. $\times 25^{\circ}$.

Fig. 9. Griselinia lucida. Radial section of root, showing diffuse parenchyma not noticed in transverse section. $\times 25^{\circ}$.

Fig. I0. Shefflera sp. Transverse section of stem, showing vasicentric parenchyma. $\times 250$. $\times 250$.

Fig. I I. Schefflera $s p$. Radial section of stem, showing parenchyma clustered over vessels.

Fig. I2. Schefflera sp. Tangential section of stem, showing vasicentric parenchyma and also septate tracheides. $\times 250$.

\section{PLATE V.}

Fig. I3. Acanthopanax senticosus. Tangential section of stem, showing vasicentric parenchyma and vessel with simple elliptical pore placed obliquely to lateral walls. $\times 25^{\circ}$.

Fig. 14. Cicuta bulbifera. Transverse section of stem, showing terminal walls of vasicentric parenchyma. $\times 25^{\circ}$.

Fig. I5. Cicuta bulbifera. Radial section of stem, showing vasicentric parenchyma and vessel with simple terminal pore. $\times 25^{\circ}$.

Fig. 16. Cicuta bulbifera. Tangential section of stem, showing vasicentric parenchyma and vessel with simple round pore in end wall. $\times 25^{\circ}$. $\times 250$.

Fig. 17. Fuglans nigra. Transverse section of stem, showing example of diffuse parenchyma.

Fig. 18. Fraximus americana. Transverse section of stem, showing example of vasicentric parenchyma. $\times 250$. 
Annals of Botany.
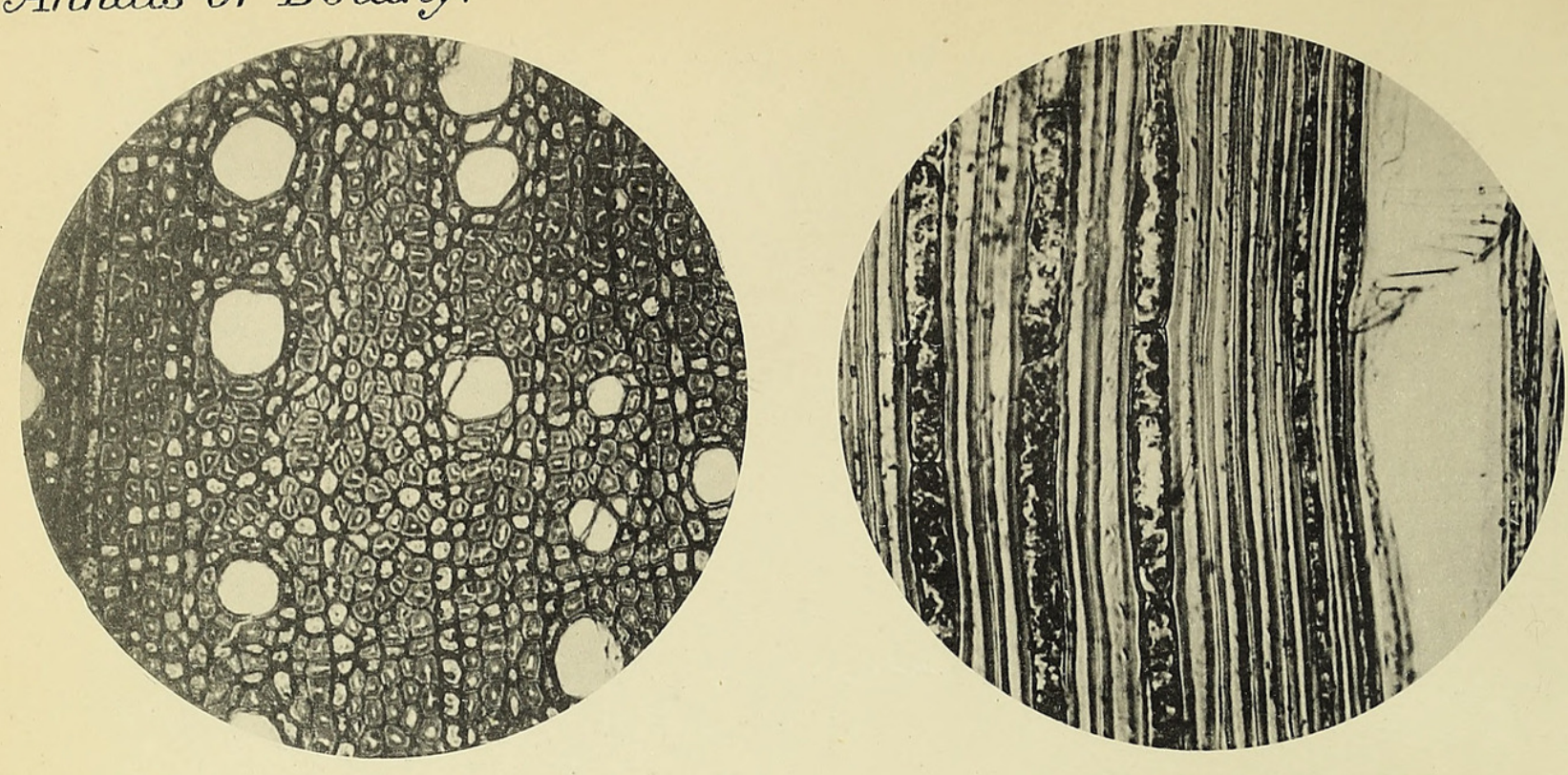

2

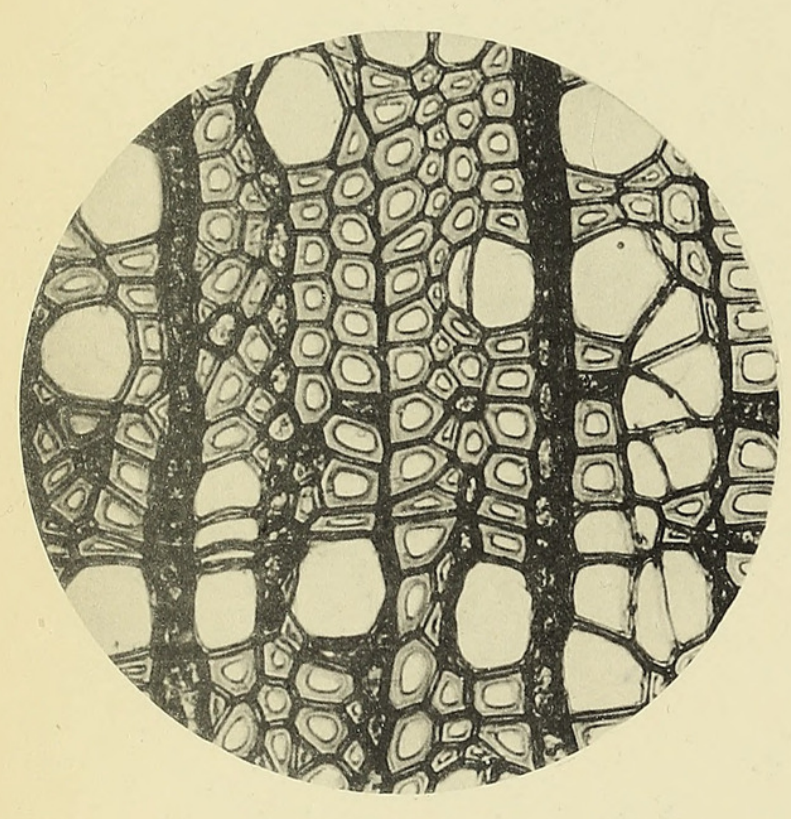

3.

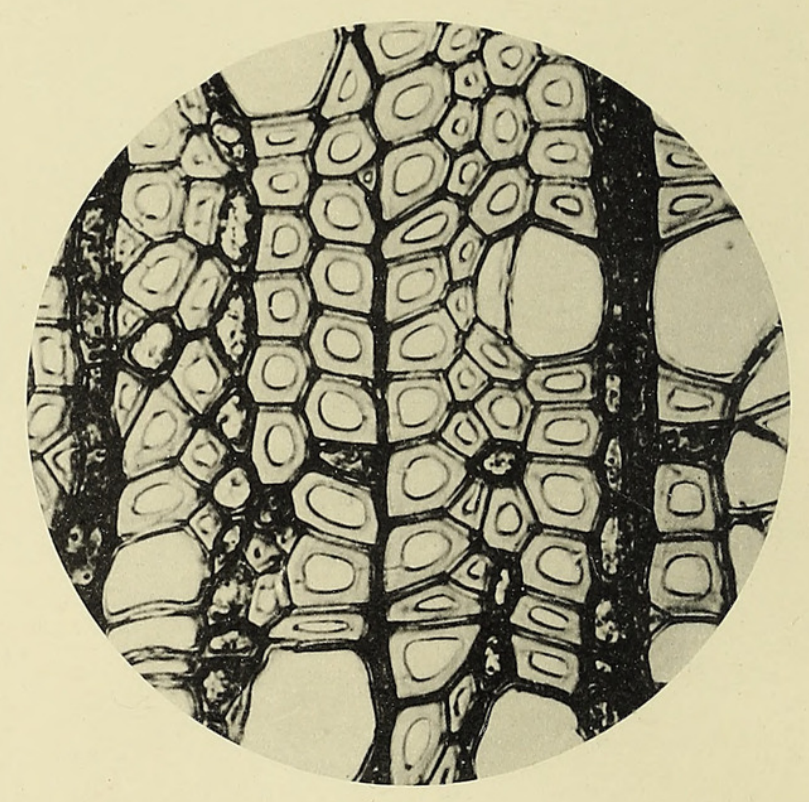

4.
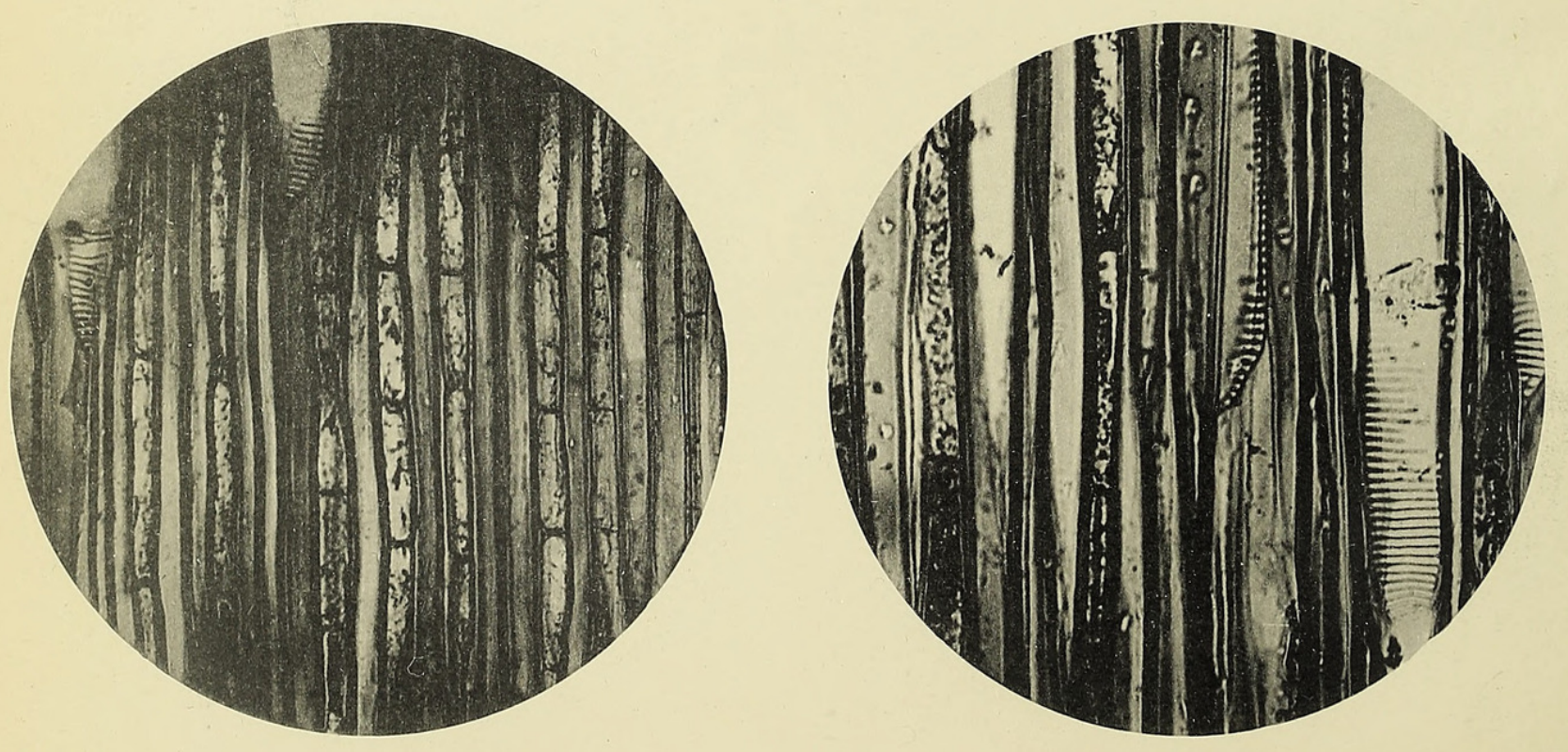

5.

6. HOAR - UMBELLIFLORAE. 


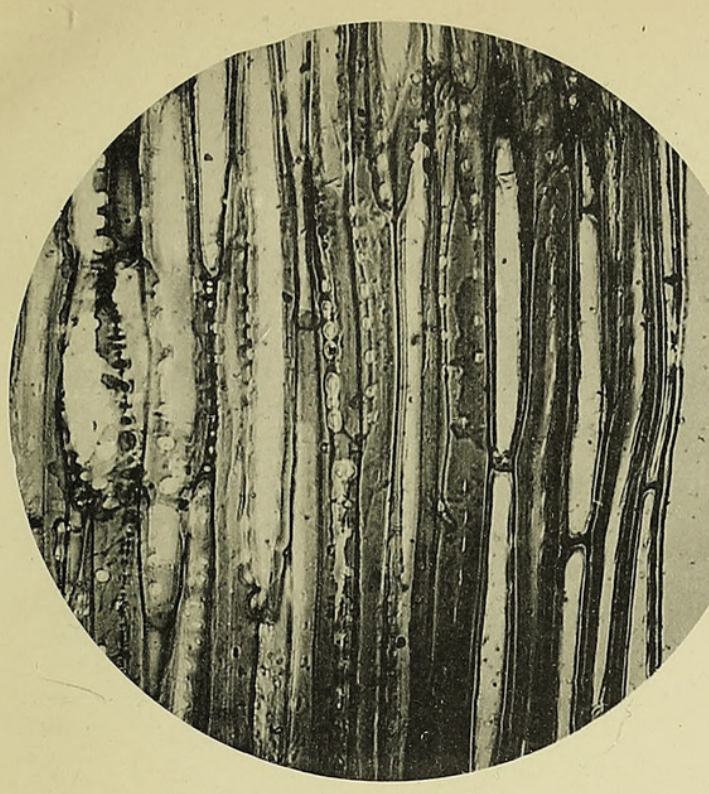

7.

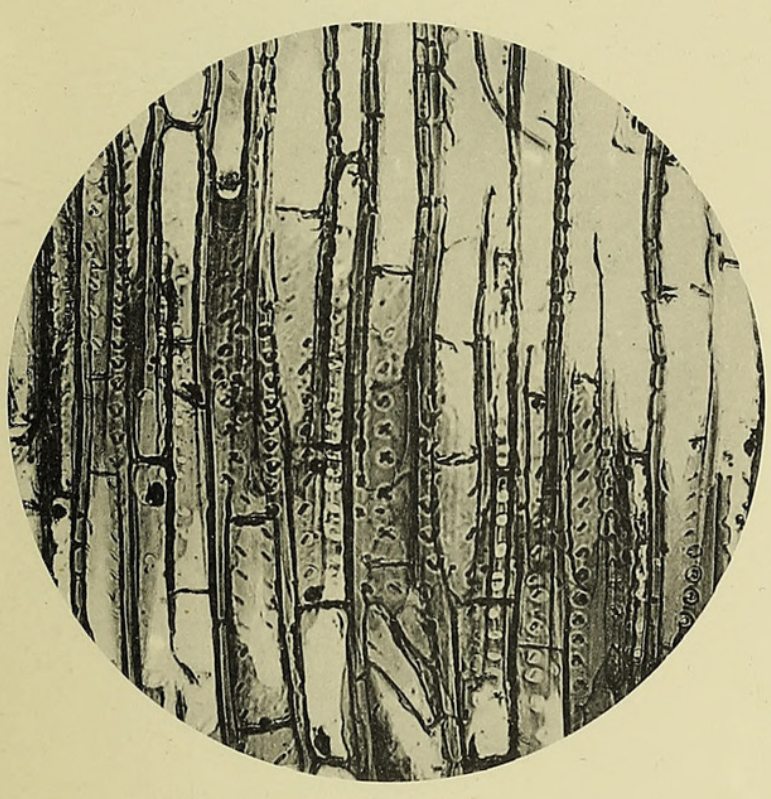

9.

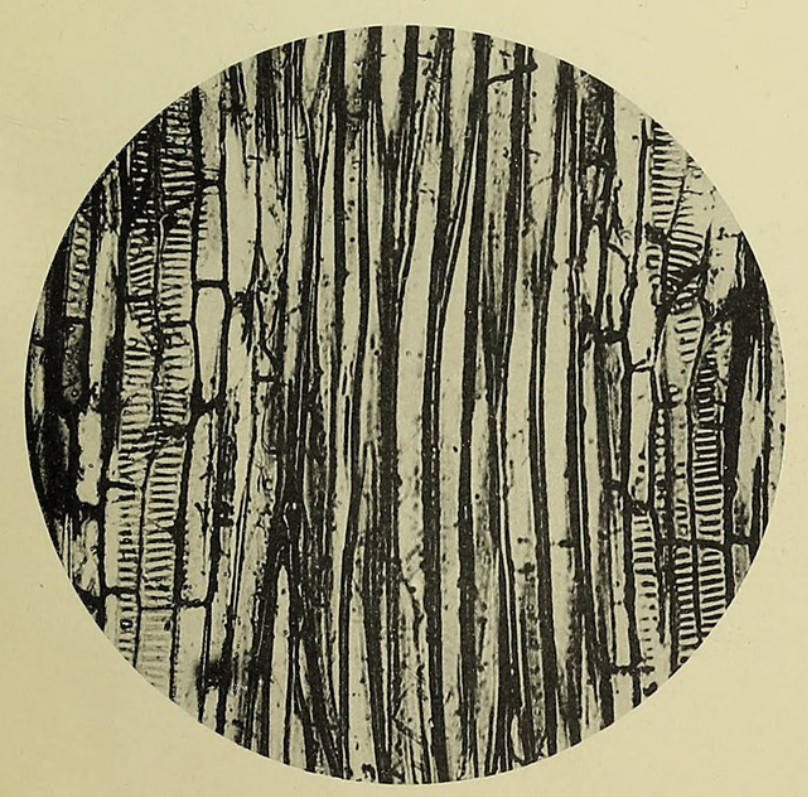

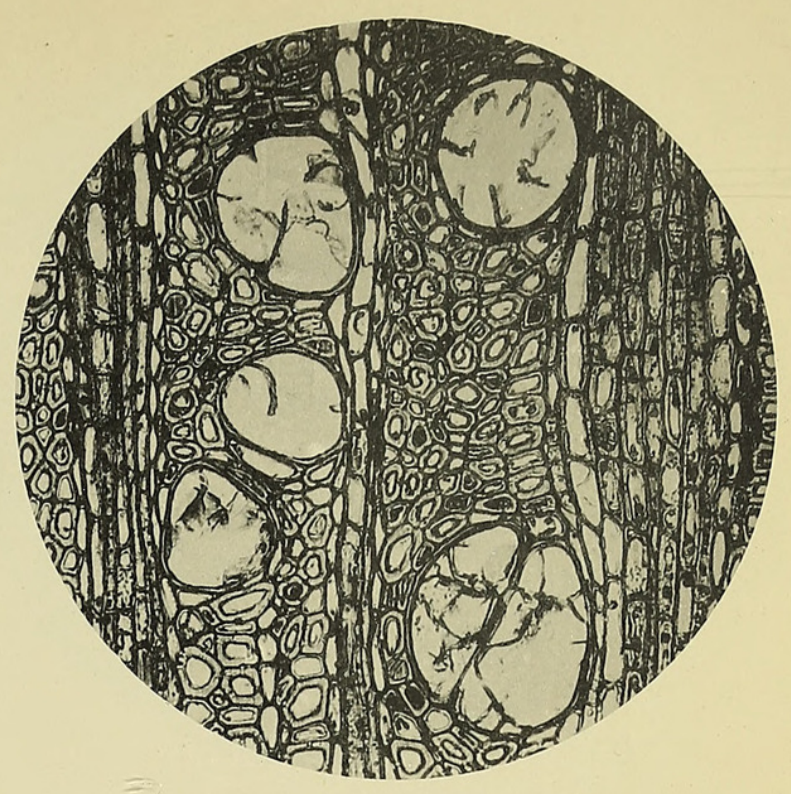

8
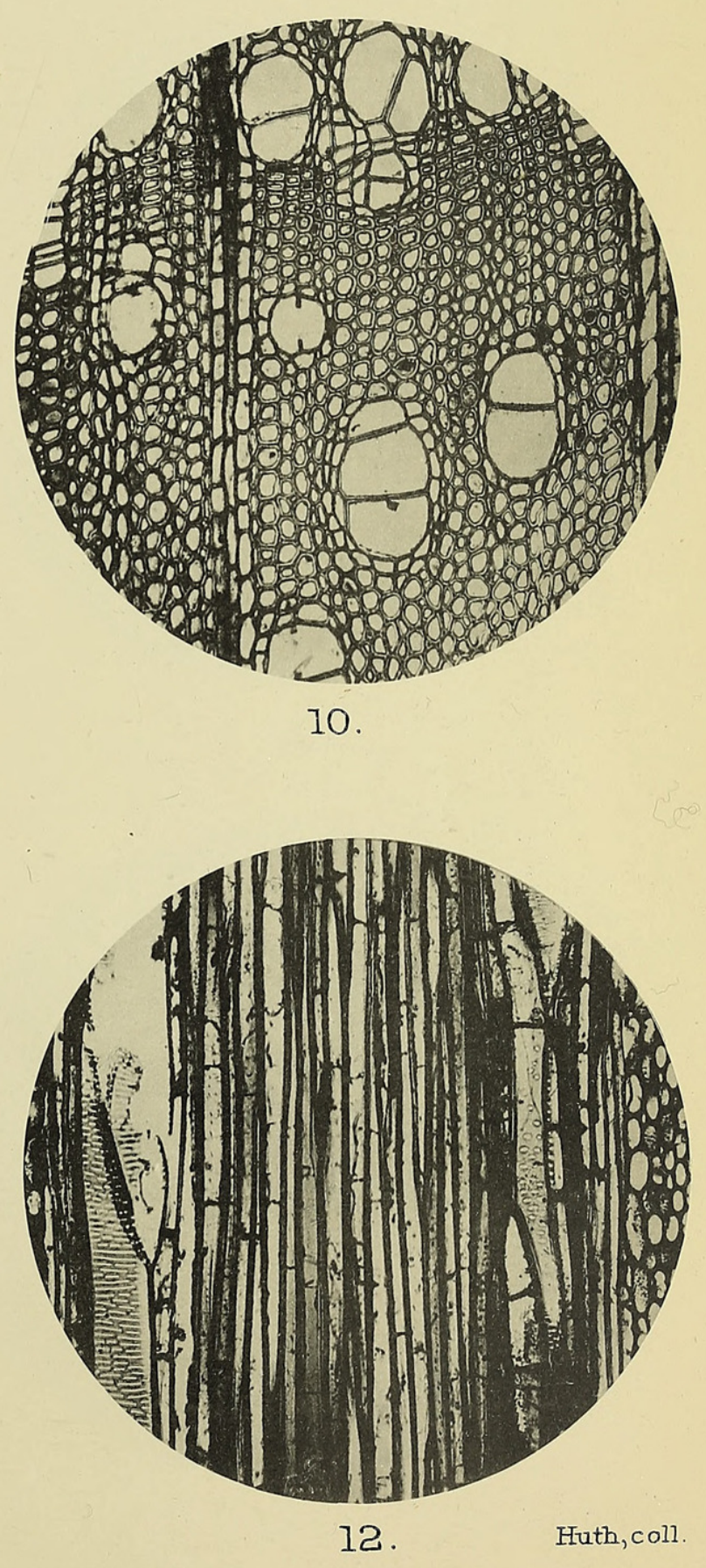
Annals of Botany.

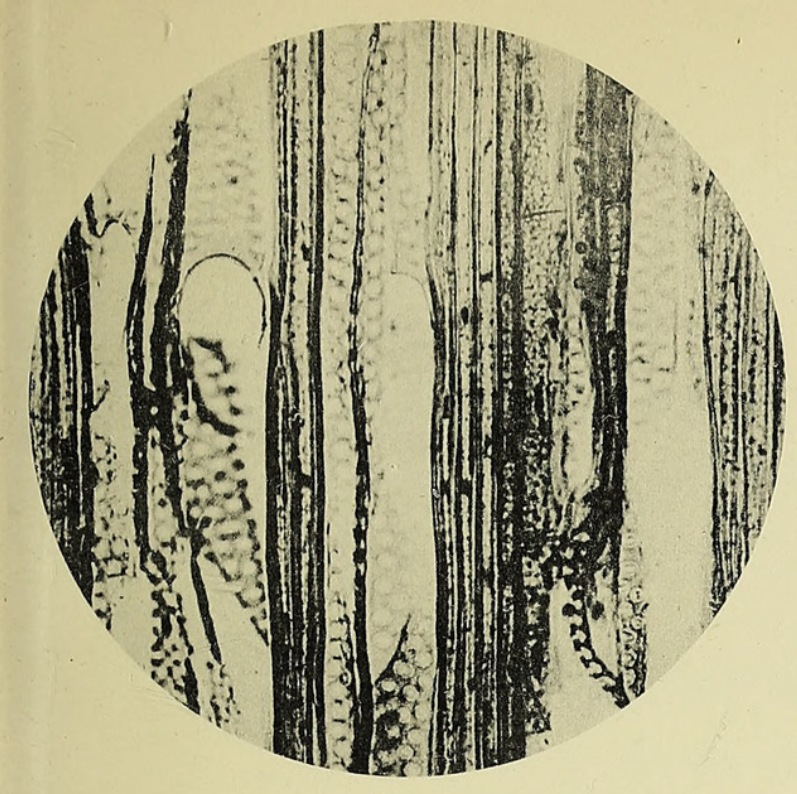

13

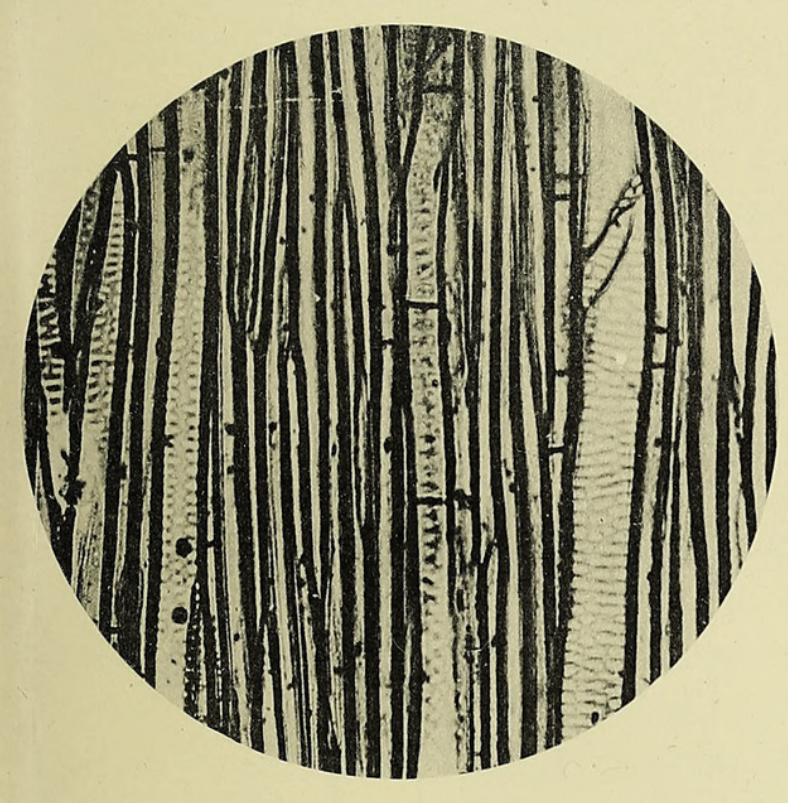

15.

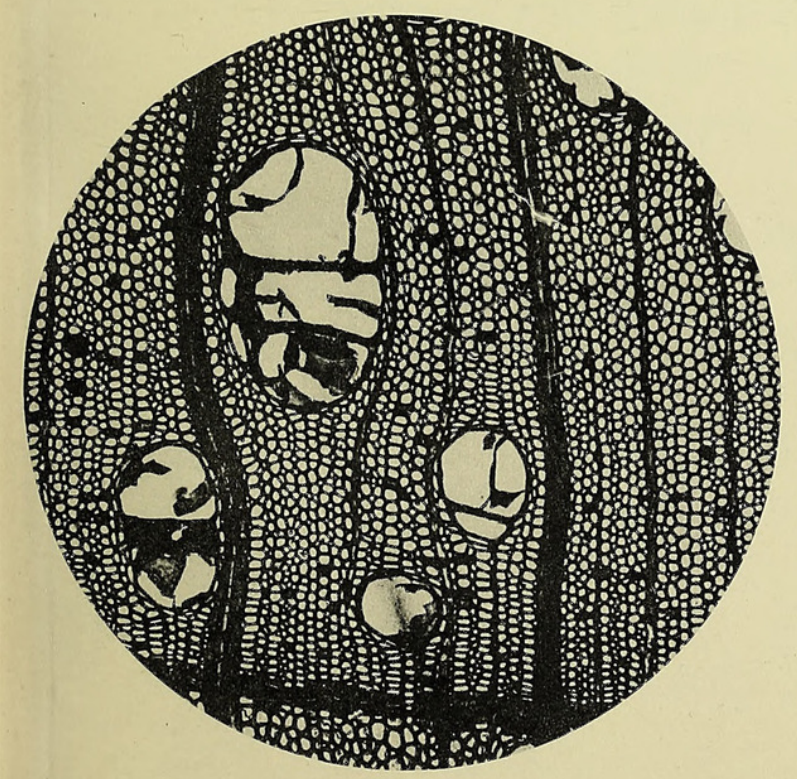

17.

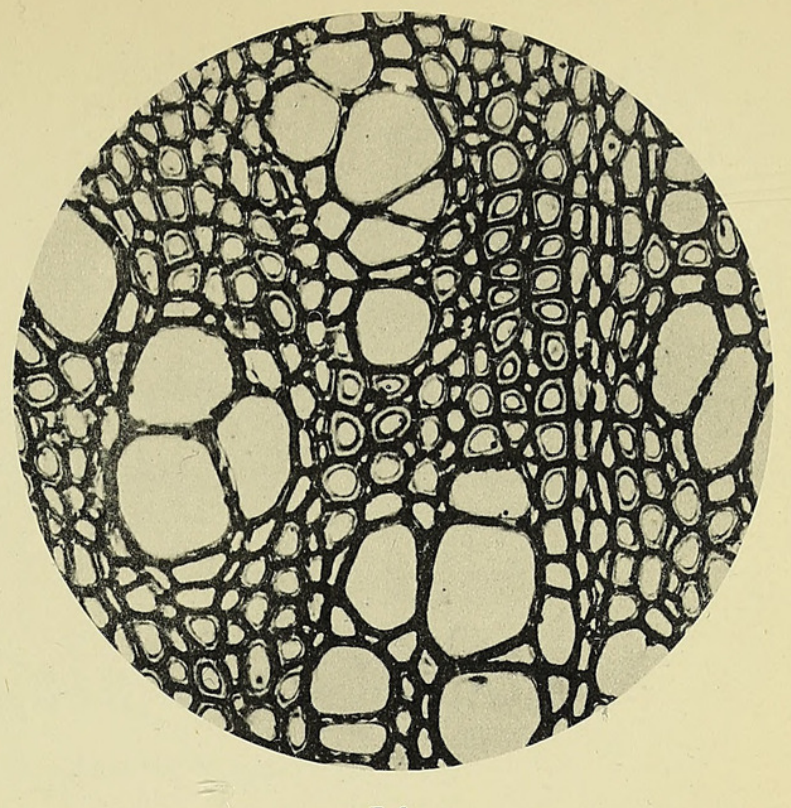

14

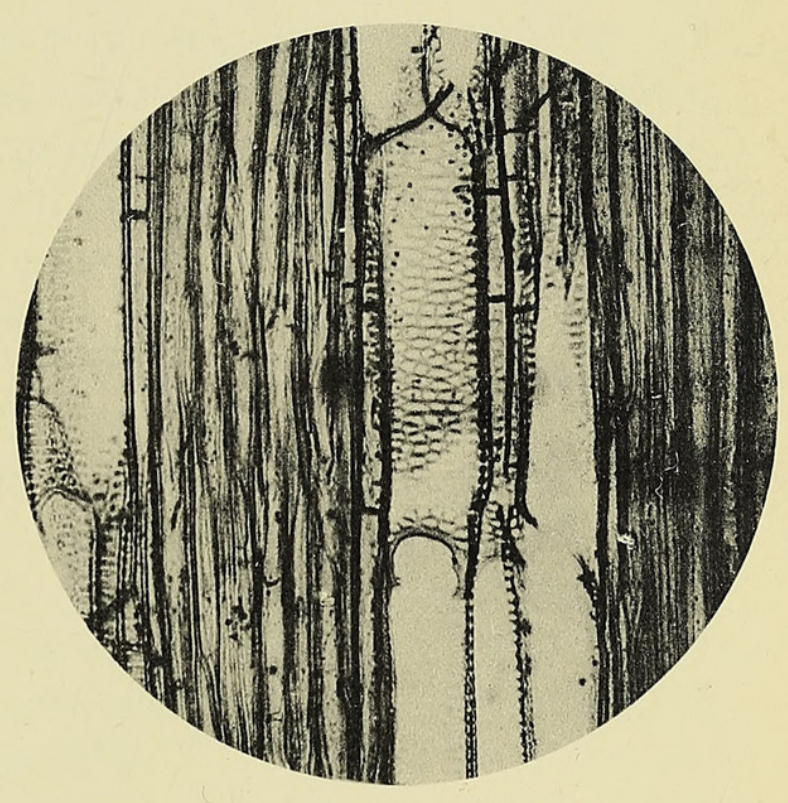

16.

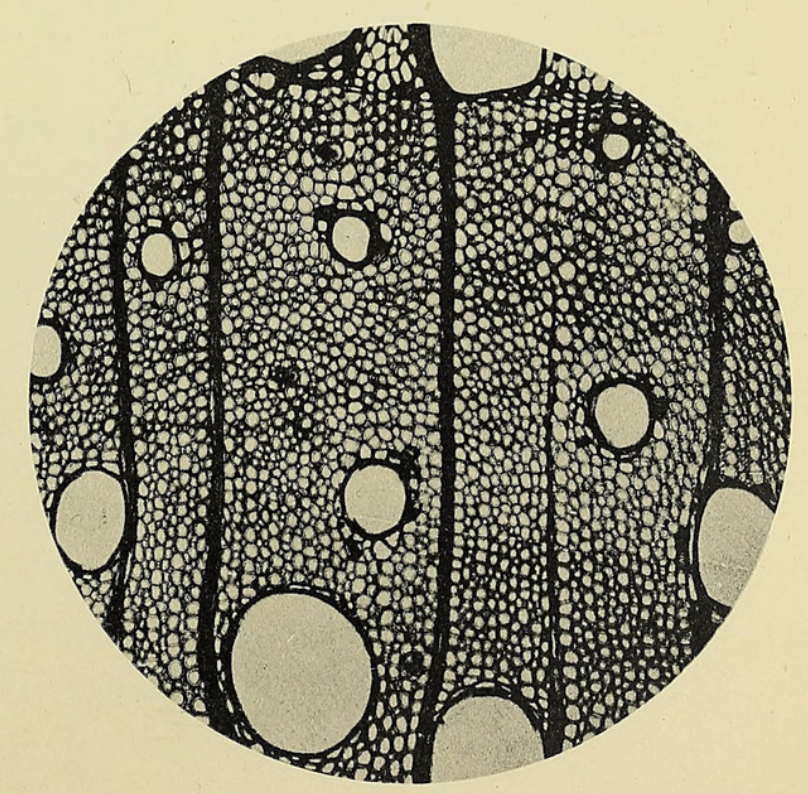

18.

Huth, coll

HOAR - UMBELLIFLORAE. 


\section{$2 \mathrm{BHL}$ Biodiversity Heritage Library}

Hoar, Carl Sherman. 1915. "A comparison of the stem anatomy of the cohort Umbelliflorae." Annals of botany 29, 55-63.

https://doi.org/10.1093/oxfordjournals.aob.a089537.

View This Item Online: https://www.biodiversitylibrary.org/item/243629

DOI: https://doi.org/10.1093/oxfordjournals.aob.a089537

Permalink: https://www.biodiversitylibrary.org/partpdf/320050

\section{Holding Institution}

Smithsonian Libraries

\section{Sponsored by}

Biodiversity Heritage Library

\section{Copyright \& Reuse}

Copyright Status: Not in copyright. The BHL knows of no copyright restrictions on this item.

This document was created from content at the Biodiversity Heritage Library, the world's largest open access digital library for biodiversity literature and archives. Visit BHL at https://www.biodiversitylibrary.org. 